\title{
Behavioral Ability and Division of Forestry Production of Households_Data From Fujian Province in China
}

\author{
Yaping Wen ${ }^{1, \mathrm{a}}$, Liangming Feng ${ }^{1, \mathrm{~b}}$, Weiping Liu $^{1,2, \mathrm{c}^{*}}$ \\ ${ }^{1}$ College of Economics, Fujian Agriculture and Forestry University, Fuzhou, China; \\ ${ }^{2}$ Collective Forestry Reform and Development Research Center, National Forestry and Grassland Bureau, Fuzhou, China
}

\begin{abstract}
Division of labor can increase labor productivity. Compared with the division of agricultural production, the division of forestry production has a typical positive externality. It is more scientific to study the division of labor in forestry production. Under the "Three Powers Separated" structure, the behavioral capacity of farmers has an important influence on the division of forestry production. This paper uses the survey data of farmers in Fujian Province to analyze the farmer's forestry production division of labor behavior from three perspectives of the behavioral ability, the transaction ability and the disposal ability. The results show that the variable of "the contracting right is more important than the management right" in the measure exclusive ability and the difficulty in obtaining transaction information on forestlands to measure the trading capacity, both positively affects farmers' participation in the division of forestry production. Meanwhile, whether has changed the use of forestlands negatively influences the division of the forestry production. This not only enriches the research results of the forestry production division of labor theory, but also provides a new perspective for promoting the development of the forestry production division of farmers, and thus provides a new source for improving the efficiency of forestry management. It helps promote the connection between small farmers and the development of modern forestry.
\end{abstract}

\section{INTRODUCTION}

"Division of Labor can increases productivity"[1]. Since the publication of "An Inquiry into the Nature and Causes of the Wealth of Nations", the division of labor has attracted much attention in academic circles. With the development of economy and society, the agriculture has had a qualitative leap in the production technology, the management level and the factor allocation capacity. The openness of the modern agriculture has solved the "Smith Guess", and then the agriculture is the practical separability ${ }^{[2]}$. Now it has formed the increasingly perfect the service market in the division of labor, and has implemented the scale management of the scattered land. Finally, it has improved the efficiency of agricultural management ${ }^{[3-5]}$. At present, the academic circle has conducted extensive and in-depth research on the division of labor in agricultural production. The division of labor in the agricultural production is the "golden key" to open agricultural scale management ${ }^{[6]}$. The modern agriculture has had a division in realistic, but decision-making behaviors and degrees of the labor

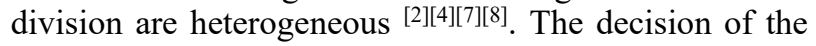
division of labor is a rational choice after measuring the opportunity cost of farmers to fully engage in agricultural production and the labor productivity gap with specialized suppliers ${ }^{[8]}$, which is mainly affected by the following factors: First is the land factor, such as the planting scale, the degree of the land fragmentation and subsidies; Second is the farmer including the age, the education level, the off-farm wages, the number of labor force, the aging of the labor force and the degree of part-time employment; Third is the capital factor containing the value of the agricultural machinery, the service price of the machinery, the family income and the proportion of agricultural incomes; Fourth is technology factors and other factors, including technical trainings, transaction costs and the market size, etc. ${ }^{[2][6][7][9-19] . ~ T h e ~ e x i s t i n g ~ r e s e a r c h ~ b a s e d ~ o n ~}$ multidimensional, to traditional crops such as rice, wheat, corn, soybean, for example, the division of agricultural production, farmers provides fruitful research results, however, cover multiple agricultural industry, the particularity of each industry has its own development, whether these theoretical research conclusions by extension, suitable to all industries, scholars did not answer. From many dimensions, the existing research takes rice, wheat, corn, soybeans and other traditional crops as examples, and provides fruitful research results for the division of the agricultural production. But the agriculture covers a variety of industries, and each industry has its own development of the particularity. Thus, whether these theoretical conclusions can be

e-mail: a874601752@qq.com; b519724658@qq.com

Corresponding author: Weiping Liu *e-mail: clwp789326@126.com 
pushed widely to suit for other industries, scholars have not given answers.

Forestry belongs to generalized agriculture, but it has its own particularities. The particularity mainly reflected in: compared with the agriculture, the scale of forestry production is relatively higher, and the mechanization level and the technical level in the production and management are relatively lagging behind, and the production and the management have a strong positive externality because of its ecological value. The development of the division of labor not only follows the agricultural general laws of division of labor, but also has its own characteristics. Then, what are the status of the division of labor in the development of forestry? What are main factors? The existing research does not provide corresponding answers. In view of this, under the background of the "Three Powers Separated", this paper analyzes the impact of different behavioral capabilities on the division of labor in the forestry production from the perspective of subdivision of management rights. It not only enriches the theoretical research results on the division of forestry production, but also provides a new impetus for promoting the development of the division of labor in the forestry production. It provides a new source for improving the efficiency of forestry management, and finally helps to accelerate the effective connection between small farmers and the development of modern forestry.

\section{THEORETICAL MECHANISM}

Since 2002, a new round of collective forest right reform has implemented the policy of "forest division to household", which has transformed forestland management from collective management to family management, breaking the scale of forestry management and starting the fragmentation of small farmers. Since then, it is a better choice to achieve large-scale management of forestlands through the transfer of forest rights in order to meet the internal requirements of large-scale management of forestlands, improve management efficiency, and promote modernization of forestry. However, forestlands have a strong "endowment effect", the property value, the reputation value, and the security value, which leads to a slow circulation process ${ }^{[20-23]}$. According to the monitoring results of the reform of the collective forest rights system in 2017, as of the end of 2016, the total area of collective forestlands transferred was 0.178 million ha, accounting for $9.97 \%$ of the area of forestlands that has been confirmed. From 2010 to 2016, the average proportion of farmers who were unwilling to transfer forestlands is $81.22 \%{ }^{[24]}$. However, the scale management includes not only the scale management of land, but also the scale management of services ${ }^{[25]}$. The essence of the scale management is the division of labor economy ${ }^{[20]}$. At the same time, the increasing number of specialized service providers and the use of specialized assets such as the high-valued and high-efficiency machineries have improved the productivity of the division of labor services. Therefore, it has become the choice of most farmers to improve the efficiency of forestlands management through the division of services in the forestry production market.
Under the pattern of "Three Powers Separated", release of the right to operate has become the only way for farmers to participate in the market of the division of labor service. According to Luo's theorem, when the transaction cost exists, if property allocation efficiency cannot be improved through the reallocation of property rights, it may be appropriate to match them through further subdivision of property rights and circuited transactions ${ }^{[20]}$. Barzel (1989) ${ }^{[26]}$ pointed out that the property right is an individual's ability to consume a property directly or indirectly through transactions. Property right is a bundle of rights with the ability to subdivide, restructure and trade, and the premise of trade is that property right is clearly defined. The more stable the property right may not be the better. The smallholder farmers can be included into the division of labor system through the subdivision of the management right, and then the forestry operation efficiency can be improved. The division of the management right will form a diversified principal-agent market ${ }^{[27]}$, so that it promotes the comparative advantage subjects with the "management knowledge" or the "professional production knowledge" to enter segment markets ${ }^{[20]}$. At this time, farmers only need to transfer the production rights of different links to the main body with comparative advantages, and then they can participate in the division of labor market. However, most scholars believe that the comparative advantage can be expressed through the behavioral capacity of property rights ${ }^{[27-29]}$. After all, according to the theory of property right economics, the essence of the division of labor is the subdivision and the allocation of property rights, and the property rights' separation achieves the matching between the personal knowledge and the exercise of rights, which is an effective way to play the comparative advantage. Therefore, it is reasonable to analyze the comparative advantage from the perspective of behavior ability.

According to the connotation of property rights, the behavioral ability of property rights can be measured by the exclusive ability, the disposal ability and the transaction ability ${ }^{[28-31]}$. Firstly, the exclusive ability mainly reflects the definition, control and exclusivity of the property right. It includes the exclusive ability of the contracting right and the exclusive ability of the management right ${ }^{[20]}$. The former refers to whether the contract right is stable, and the latter refers to whether the forestry income belongs to their own. The stronger the exclusivity, the clearer the definition of property right, the lower the transaction cost of property right and the greater the probability of participating in the division of labor. Secondly, the transaction ability refers to the ability of both parties to transfer or mortgage by contract, which is mainly manifested as circulation, mortgage, and shareholding ${ }^{[31]}$. The stronger the transaction ability is, the stronger the ability of farmers to benefit from forestlands transfer or mortgage by contract is, and the less forestlands farmers themselves operate, and the weaker the willingness to participate in production division is. Finally, the disposal ability mainly refers to the partition of various rights of forestry resources to make them in a temporary or even permanent on the basis of distribution between the main body of two or more. However, according to the regulations on the 
implementation of the forestry law, the change of the forestry use requires the approval of the competent forestry authorities of the people's government at or above the county level. Therefore, the stronger the disposal ability is, the greater the space for resource reconfiguration is, the greater the possibility to give up the forestland is, and the lower the probability of participating in the division of production is.

In conclusion, the research hypothesis of this paper is as follows:

Hypothesis 1: the stronger the exclusive ability, the more likely it is for farmers to participate in the division of the forestry production.

Hypothesis 2: the stronger the transaction ability, the less chance farmers have to participate in the division of the forestry production.

Hypothesis 3: the stronger the disposal ability, the lower the probability of farmers participating in the division of forestry production.

\section{DATA}

The data used in this paper are from the field survey conducted by the research team of Fujian Agriculture and Forestry University from August to October 2019. The survey was mainly conducted in the form of questionnaire sampling survey, and the main areas were Sha county, Youxi County and Wuping County in Fujian Province. Fujian Province is located in the southeast of China. In 2019, the province's per capita GDP is 107,139 yuan. As one of the key forest regions in the south of China, Fujian Province ranks the first in the forest coverage rate in China for 40 consecutive years and has abundant forest resources. In 2002, Wuping County in Fujian Province took the lead in the national reform of collective forest rights, and was called "the first county of forest reform". In 2003, the whole province carried out the reform of collective forest right system, which was one of the first provinces to carry out the reform. In 2006, Fujian Province further deepened the reform of collective forest rights. By clarifying property rights and implementing management subjects, it effectively aroused the enthusiasm of the number of farmers to cultivate and protect forests, and promoted the development of the forest production, the resource growth, the farmers' income, the village finance and the social harmony. Meanwhile, the reform accelerated the development of the rural economy and society.

The selection of sample areas by the research group mainly follows the standards of good development and feasible investigation of the division of labor in forestry production links. Therefore, the selection of sample provinces and counties is not a random method. Based on the feasible investigation, Sha County, Youxi County and Wuping County were selected because of their more forestry production activities in recent three years. In the sample survey, a total of 20 towns of the three counties in Fujian Province were selected as the survey areas. The specific sampling methods are as follows: firstly, in the sample County, according to the list of villages and towns provided by the person in charge and the afforestation situation in recent 3 years, we select the sample villages and towns by stratified sampling. Secondly, we randomly select the sample villages and sample households, and there are selected about 11 households in each township. Finally, a total of 243 households from 20 sample villages were sampled. We send out a total of 243 questionnaires, of which 231 were valid. The effective rate is $95.06 \%$. The data of questionnaire survey is the main data source of this paper.

\section{THE MODEL}

Considering that farmers often only have a single choice of "yes or no" when making outsourcing decisions, Logit model in the binary selection model is selected to carry out empirical study. The Logit model generally sets the probability function of farmers' selection as the cumulative distribution function of logical distribution, and the maximum likelihood method (MLE) can be used to estimate the selection of estimation methods. The model expression is as follows:

$Y_{i}=\propto+\sum_{i=1}^{n=5} \beta_{1 i} X_{1 i}+\sum_{i=1}^{n=4} \beta_{2 i} X_{2 i}+\sum_{i=1}^{n=2} \beta_{3 i} X_{3 i}+$ $\sum_{i=1}^{n=5} \gamma_{i} C_{i}+\varepsilon$

In the above formula, $\alpha, \beta, \gamma, \mathrm{i}$ and $\varepsilon$ are constants, and $\alpha, \beta$ and $\gamma$ are parameters to be estimated. And $i$ is the number of variables. $\varepsilon$ is the random error term which is independent of key variables and control variables and obeys the normal distribution.

$Y_{i}$ represents the selection of division of different farmer, that is, if farmers participate in the division of the forestry production, the value of "yes" is one. Otherwise the value of "no" is zero. In this paper, the process of the forestry production mainly contains afforestation, tending (including fertilization and weeding), protection (including fire prevention, pest control, theft prevention, etc.) and cutting. The form of participation in the division of labor is outsourcing or employing specialized labor force engaged in forestry production. Generally, the production activities that are completed by farmers themselves are not included in the division of labor, but farmers themselves who are professional workers are exceptions. In summary, the division of forestry production of farmers includes outsourcing, hiring professional labor and self-employment of professional labors.

The behavioral ability is expressed by the exclusive ability, the transaction ability and the disposal ability. The exclusive ability $\left(\mathrm{X}_{1}\right)$ is mainly measured by whether the contracting right is stable, the consent to the government's right to expropriate forestlands, whether the forestry income of farmers is completely owned by themselves, the consent that the contracting right is more important than the management right, and whether there is a dispute over the forest right. The transaction ability $\left(\mathrm{X}_{2}\right)$ mainly includes the degree of decision on the transaction price, the degree of decision on the transaction location and quantities, the difficulty of obtaining the transaction information of forestlands and the number of channels for obtaining the technical information of forest. The disposal ability $\left(\mathrm{X}_{3}\right)$ is expressed by whether the use of forestlands has been 
changed and the number of channels for obtaining the price information of forest products.

In order to optimize the model, the control variables $(\mathrm{C})$ need to be added and include the characteristics of farmers and the forestland. The

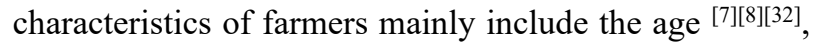
the number of afforestation experiences and the proportion of surrounding farmers participating in the division of labor. Woodland features mainly include the area of forestlands ${ }^{[7][8][10][32]}$ and the amount of forestry subsidies ${ }^{[13][28][33]}$. As for farmers, the older they are, the lower their ability to accept new things and the less likely they are to participate in the division of labor. The more afforestation they have done, the more likely they are to master the forestry production technology, so as to inhibit their choice of division of labor services. The proportion of surrounding farmers participating in the division of labor is directly related to the transaction cost in the division of labor market. The higher the ratio is, the lower the transaction cost of the division of labor market is, and the more likely farmers are to participate in the division of labor. In the meanwhile, the larger the forestland area is, the more difficult it is for farmers to carry out production activities by themselves and the more likely it is to restrain farmers from participating in the division of labor.

There are two aspects of the role of forestry subsidies in the division of production. A large amount of forestry subsidies will reduce the total cost of farmers' forestry production, and then promote them to participate in the division of forestry production. What's more, these farmers have comparative advantages in the access to forestry production information, so it's easier for them to carry out their own production. Whether the farmers ultimately participate in the division of labor depends on which of these two functions is greater.

The names, definitions and descriptive statistical results of variables are shown in table 1.

TABLE I DESCRIPTION OF VARIABLE

\begin{tabular}{|c|c|c|c|c|}
\hline \multicolumn{2}{|l|}{ Variable } & Definition & Mean & S. D \\
\hline \multicolumn{2}{|c|}{ Dependent variable } & $\begin{array}{l}\text { Whether to participate in the division of } \\
\text { labor(Yes=one, No=zero) }\end{array}$ & 0.835 & 0.372 \\
\hline \multirow{11}{*}{$\begin{array}{l}\text { Behavioral } \\
\text { ability }\end{array}$} & \multirow{5}{*}{$\begin{array}{l}\text { Exclusive } \\
\text { ability }\end{array}$} & $\begin{array}{l}\text { Whether the contracting right is stable }(\mathrm{Yes}=\mathrm{one} \text {, } \\
\text { No=zero) }\end{array}$ & 0.939 & 0.239 \\
\hline & & $\begin{array}{l}\text { Consent to the government's right to expropriate the } \\
\text { forestland }(1=\text { very agree; } 2=\text { relatively agree; } 3= \\
\text { average; } 4=\text { not agree; } 5=\text { very disagree })\end{array}$ & 2.472 & 1.236 \\
\hline & & $\begin{array}{l}\text { Whether the forestry income of farmers is completely } \\
\text { owned by themselves(Yes }=\text { one, } \mathrm{No}=\text { zero) }\end{array}$ & 0.913 & 0.282 \\
\hline & & $\begin{array}{l}\text { Consent that the contracting right is more important } \\
\text { than the management right }(1=\text { very agree; } 2=\text { relatively } \\
\text { agree; } 3=\text { average; } 4=\text { not agree; } 5=\text { very disagree })\end{array}$ & 2.745 & 1.176 \\
\hline & & $\begin{array}{l}\text { Whether there is a dispute over the forest } \\
\text { right(Yes=one, No=zero) }\end{array}$ & 0.078 & 0.267 \\
\hline & \multirow{4}{*}{$\begin{array}{l}\text { Transaction } \\
\text { ability }\end{array}$} & $\begin{array}{l}\text { Degree of decision on the transaction } \\
\text { price }(1=\text { absolutely; } 2=\text { more able; } 3=\text { generally; } 4=\text { less } \\
\text { able; } 5=\text { not at all) }\end{array}$ & 2.714 & 1.369 \\
\hline & & $\begin{array}{l}\text { Degree of decision on the transaction location and } \\
\text { quantities }(1=\text { absolutely; } 2=\text { more able; } 3=\text { generally; } \\
4=\text { less able; } 5=\text { not at all })\end{array}$ & 2.844 & 1.424 \\
\hline & & $\begin{array}{l}\text { Difficulty of obtaining the transaction information of } \\
\text { the forestland }(1=\text { very easy; } 2=\text { relatively easy; } 3= \\
\text { General; } 4=\text { relatively difficult; } 5=\text { very difficult })\end{array}$ & 2.342 & 1.198 \\
\hline & & $\begin{array}{l}\text { Number of channels for obtaining the technical } \\
\text { information of forest }(1=\text { very much; } 2=\text { more; } 3= \\
\text { average; } 4=\text { less; } 5=\text { very little })\end{array}$ & 3.342 & 1.234 \\
\hline & \multirow{2}{*}{$\begin{array}{l}\text { Disposal } \\
\text { ability }\end{array}$} & $\begin{array}{l}\text { Whether the use of forestlands has been } \\
\text { changed(Yes }=\text { one, } \mathrm{No}=\text { zero) }\end{array}$ & 0.100 & 0.300 \\
\hline & & $\begin{array}{l}\text { Number of channels for obtaining the price information } \\
\text { of forest products(times) }\end{array}$ & 1.143 & 0.397 \\
\hline \multirow{5}{*}{\multicolumn{2}{|c|}{ Control variables }} & Age(years) & 54.481 & 8.464 \\
\hline & & Number of afforestation experiences (times) & 6.320 & 9.502 \\
\hline & & $\begin{array}{l}\text { Proportion of surrounding farmers participating in the } \\
\text { division of labor }(\%)\end{array}$ & 76.139 & 29.878 \\
\hline & & Area of forestlands(Mu) & 79.646 & 96.505 \\
\hline & & Amount of forestry subsidies(RMB) & $\begin{array}{l}13801.6 \\
60\end{array}$ & $\begin{array}{l}29844.8 \\
70\end{array}$ \\
\hline
\end{tabular}




\section{RESULTS AND DISCUSSION}

The binary Logit Model is used to demonstrate the relationship between the behavioral ability and the division of labor in the forestry production. The results are shown in table 2. It can be seen from the table that some variables significantly affect the division of
Data source: household surveys. forestry production of farmers, such as the consent that the contracting right is more important than the management right, the difficulty of obtaining forestland transaction information, whether forestland use has been changed, the number of previous afforestation experiences, the proportion of surrounding farmers participating in the division of labor, and the forestland area. The details are as follows:

TABLE II THE ESTIMATED RESULTS

\begin{tabular}{|c|c|c|c|c|}
\hline \multicolumn{2}{|l|}{ Variable } & & $\begin{array}{l}\text { Coefficient (Standard } \\
\text { error) }\end{array}$ \\
\hline \multirow{11}{*}{$\begin{array}{l}\text { Behavio } \\
\text { ral } \\
\text { ability }\end{array}$} & \multirow{5}{*}{$\begin{array}{l}\text { Exclusive } \\
\text { ability }\end{array}$} & \multicolumn{2}{|c|}{ Whether the contracting right is stable } & $-0.577(1.005)$ \\
\hline & & \multicolumn{2}{|c|}{$\begin{array}{l}\text { Consent to the government's right to expropriate the } \\
\text { forestland }\end{array}$} & $-0.028(0.191)$ \\
\hline & & \multicolumn{2}{|c|}{$\begin{array}{l}\text { Whether the forestry income of farmers is completely } \\
\text { owned by themselves }\end{array}$} & $-0.209(0.878)$ \\
\hline & & \multicolumn{2}{|c|}{$\begin{array}{l}\text { Consent that the contracting right is more important than } \\
\text { the management right }\end{array}$} & $0.380^{*}(0.206)$ \\
\hline & & \multicolumn{2}{|c|}{ Whether there is a dispute over the forest right } & $-0.685(0.747)$ \\
\hline & \multirow{4}{*}{$\begin{array}{l}\text { Transacti } \\
\text { on ability }\end{array}$} & \multicolumn{2}{|c|}{ Degree of decision on the transaction price } & $-0.031(0.215)$ \\
\hline & & \multicolumn{2}{|c|}{$\begin{array}{l}\text { Degree of decision on the transaction location and } \\
\text { quantities }\end{array}$} & $-0.298(0.212)$ \\
\hline & & \multicolumn{2}{|c|}{$\begin{array}{l}\text { Difficulty of obtaining the transaction information of the } \\
\text { forestland }\end{array}$} & $0.381^{*}(0.211)$ \\
\hline & & \multicolumn{2}{|c|}{$\begin{array}{l}\text { Number of channels for obtaining the technical information } \\
\text { of forest }\end{array}$} & $-0.002(0.206)$ \\
\hline & \multirow{2}{*}{$\begin{array}{l}\text { Disposal } \\
\text { ability }\end{array}$} & \multicolumn{2}{|c|}{ Whether the use of forestlands has been changed } & $-1.331^{*}(0.798)$ \\
\hline & & \multicolumn{2}{|c|}{$\begin{array}{l}\text { Number of channels for obtaining the price information of } \\
\text { forest products }\end{array}$} & $0.108(0.691)$ \\
\hline \multirow{5}{*}{\multicolumn{2}{|c|}{ Control variables }} & \multicolumn{2}{|l|}{ Age } & $-0.040(0.028)$ \\
\hline & & \multicolumn{2}{|c|}{ Number of afforestation experiences } & $-0.033^{*}(0.020)$ \\
\hline & & \multicolumn{2}{|c|}{$\begin{array}{l}\text { Proportion of surrounding farmers participating in the } \\
\text { division of labor }\end{array}$} & $0.026^{* * *}(0.007)$ \\
\hline & & \multicolumn{2}{|c|}{ Area of forestlands } & $0.020^{* * *}(0.008)$ \\
\hline & & \multicolumn{2}{|c|}{ Amount of forestry subsidies } & $-0.005(0.000)$ \\
\hline \multicolumn{2}{|c|}{ LR $\operatorname{chi}^{2}(16)$} & 69.730 & Prob $>$ chi $^{2}$ & 0.000 \\
\hline \multicolumn{2}{|c|}{ Log likelihood } & -67.865 & Pseudo R ${ }^{2}$ & 0.339 \\
\hline
\end{tabular}

"Statistical significance at the $10 \%$ level.

${ }^{* *}$ Statistical significance at the $5 \%$ level.

${ }^{* * *}$ Statistical significance at the $1 \%$ level.

Firstly, in terms of the exclusive ability, at the significance level of $10 \%$, the degree of agreement on the importance of contracting right over the management right significantly positively affects the division of forestry production, which verifies hypothesis 1 . After all, the more farmers agree that the contract right is more important than the management right, the more willing they are to release the management right on the basis of holding the contract right, and the more likely they are to transfer the subdivision management right of different links. And then they will participate in the market of forestry production division. However, other variables are no significant impact on whether farmers participate in forestry production under the significance level of $10 \%$. There are two possible reasons. On the one hand, variables of "whether the contract right is stable" and "whether the forestry income is completely owned by themselves" have a little difference. Because $93.9 \%$ of the sample farmers have stable contract rights, and $91.3 \%$ of the sample farmers completely have their own forestry income. On the other hand, $63.2 \%$ of farmers chose "very agree" and "relatively agree" to the government's expropriation of forestlands because of the weak position of farmers and subsidies in the process of land acquisition.

Secondly, for the transaction ability, the difficulty of obtaining the forest land trading information has a positive and significant impact on the forestry production division of farmers at a significant level of $10 \%$. It means that the more difficult it is to obtain the transaction information of forestlands, the more likely it is to manage forest land itself, and then it is easier to get involved in the market of division of production, which verifies hypothesis 2 . However, under the significance 
level of $10 \%$, the degree of determination of transaction price, the degree of determination of transaction location and quantity and the number of access channels of forestry technical information have no significant impact on the division of forestry production among farmers, which may be related to the low transaction rate of forest right transfer.

Thirdly, with regard to the disposal capacity, at the significance level of $10 \%$, whether or not the use of forest land has changed has a significant negative impact on the division of the forestry production. This indicates that farmers who have changed the use of forest land have a stronger disposal capacity and a lower probability of participating in the division of the forestry production, which verifies hypothesis 3 . However, according to the relative laws and regulations, without the approval of the competent forestry authorities, farmers are not allowed to change the use of forestlands. Therefore, the disposal right of farmers is very limited in reality. In this case, most farmers choose to engage in the forestry production, and then they are more likely to be involved in the division of labor market. In addition, the number of channels of the forest product price information has no significant effect on the division of the forestry production, which may be related to the fact that farmers mainly obtain the price information from a single channel such as the forestry station or sellers.

Finally, in the control variables, the number of previous afforestation of farmers significantly negatively affects the division of the forestry production at the significance level of $10 \%$. Because the more times of previous afforestation of farmers, the higher their own afforestation technology level, the less likely they are to participate in the division of labor. In the meanwhile, the proportion of surrounding farmers participating in the division of labor and areas of the forestland have a significant positive impact on the division of the forestry production at the significance level of $1 \%$. However, under the significance level of $10 \%$, the amount of forestry subsidy has no significant effect on the division of the forestry production.

\section{CONCLUSION}

The division of labor can improve the productivity. There are differences between the division of labor in agriculture and forestry. The forestry requires the higher scale and has strong positive externalities. But the forestry is backward in the development of the mechanical level and the technical level. Under the "Three Powers Separated" pattern, the only way out is to release the management right. According to the theory of comparative advantage, the subdivision of the management right can promote the farmer with comparative advantages to enter the market of the division of labor and improves the efficiency of the forestry production. The measurement of comparative advantage can be expressed by the behavioral ability. The behavior ability can be measured from three dimensions: the exclusive ability, the transaction ability and the disposal ability. This paper mainly uses the data of farmers in Fujian Province and combines with the Logit Model and analyzes the relationship between the behavioral ability and the division of the forestry production. The empirical results show that the behavioral ability can affect the division of the forestry production. The consent that the contract right is more important than the management right and the difficulty in obtaining the forestland transaction information positively affect the participate in the division of the forestry production. But Whether the use of forestlands has ever been changed has a negative impact on the division of the forestry production. In addition, the number of previous afforestation experiences, the proportion of surrounding farmers participating in the division of labor and the area of forestlands all significantly affected the division of the forestry production.

The policy implications of the above research results are as follows: on the one hand, the subdivision of the property right is conducive to promoting the division of the forestry production, so it is of great significance to release the right of management. We should pay attention to the construction of the platform of the forest right transfer and promote the empowerment of forestlands. On the other hand, we should focus on cultivating the new-type forestry entity with the strong behavior ability and encourage and induce the market development of the forestry productive service to deepen the division of forestry production activities.

\section{ACKNOWLEDGE}

Authors are grateful for the funding provided by the National Social Science Fund's major project (No. 16ZDA024) and the Innovation Fund of Fujian Agricultural and Forestry University (No. KCXRC233A and No. KCXRC415A).

\section{REFERENCES}

[1] Adam Smith. An inquiry into the nature and causes of the wealth of nations, 1776.

[2] Jiang X.. Agricultural division of labor: outsource ability of production links. South China Journal of Economics, Vol.12, pp: 96-104, 2014.

[3] Zhang Z. and Yi Z.. Study on the impact of agricultural production service outsourcing on rice productivity. Issues in Agricultural Economy, Vol.36, pp: 69-76, 2015.

[4] Sun D., Lu Y. and Tian X.. The influence of productive services on the efficiency of rice production technology in China. Chinese Rural Economy, Vol.8, pp: 70-81, 2016.

[5] $\mathrm{Hu} \mathrm{Y}$. and Zhang Z.. The impact of agricultural machinery service on technical efficiency of wheat production. Chinese Rural Economy, Vol. 5, pp: 68-83, 2018.

[6] Wang Z., Shen H. and Liao X.. Agricultural scale management: Outsourcing from production. Chinese Rural Economy, Vol.9, pp: 4-12, 2011.

[7] Duan P. Peasant household's response to and economic effects of outsourcing in processes of 
agricultural production. Northwest A\&F University, 2018.

[8] Liu J., Zhong F., Xu Z. and Qiu H.. Heterogeneity and Causes of Farmer's Production Link Outsourcing Behavior from the Perspective of Division of Labor. Journal of Agrotechnical Economics, Vol.7, pp: 4-14, 2019.

[9] Cai R. and Cai S. Empirical research on the outsourcing of agricultural production links- based on the investigation of the main rice producing areas in Anhui Province. Journal of Agrotechnical Economics, Vol.4, pp: 34-42, 2014.

[10] $\mathrm{Hu} \mathrm{W}$; Yan J. and Chen Z. Production process outsourcing behavior of farmers and its influencing factors: Based on the perspective of factor supply and the survey data of 1134 households. Journal of Hunan Agricultural University (Social Science), Vol.17, pp: 8-14, 2016.

[11] Zhang Y. and Zhang Z.. Study on difference between demand willingness and choice behavior of peasant households' production links outsourcing — Based on empirical analysis of rice production data from Jiangsu and Jiangxi Provinces. Journal of Huazhong Agricultural University (Social Sciences Edition), Vol.2, pp: 9-14+134, 2016.

[12] Zhan J., Zhang Y. and Zhang Z.. Does Land Fragmentation Hinder the Implementation of Agricultural Production? Journal of Nanjing Agricultural University (Social Sciences Edition), Vol.16, pp: 117-124+155-156, 2016.

[13] Zhou D., Yang X. and Liu Y. Agricultural production outsourcing behavior analysis. Journal of Northwest A\&F University (Social Science Edition), Vol.16, pp: 125-129, 2016.

[14] Qian J., Chen Z., Filipski M. and Wang J.. Impact of land resources and quality on farmers' outsourcing decisions: Evidence from rice farmers in Guangxi, China. Journal of China Agricultural University, Vol.22, pp: 164-173, 2017.

[15] Zhang Q., Huo X. and Liu J.. A study on the outsourcing behaviors of apple growers: Based on the survey data of 960 households in Shanxi, Gansu and Shandong Provinces. Journal of Huazhong Agricultural University (Social Sciences Edition), Vol.2, pp: 28-36,2018.

[16] Lu. Q., Zhang C. and Qiu H.. The Influence of the aging of agricultural labor force and the co-employment of non-agricultural labor force on the outsourcing of agricultural production. Problems of Agricultural Economy, Vol.38, pp:27-34, 2017.

[17] Wang J., Huang Z., Chen Z.. Thomas R. and Jin L.. Stage outsourcing behavior in rice production under rapid transformation: An empirical study based on evidences from rice farmers in Jiangxi Province. Journal of Zhejiang University (Humanities and Social Sciences), Vol.48, pp: 33-54, 2018.

[18] Chen J. and Luo M.. The impact of farmland registration and certification on the outsourcing of rice labor-intensive production process: based on the mediating effect of agricultural machinery investment. Journal of Guangdong University of Finance \& Economics, Vol. 33, pp:98-111, 2018.

[19] Li L., Zhang Y. and Zhan X.. Study on the division of agriculture and the socialization of production. Rural Economy, Vol.2, pp: 86-91,2018.

[20] Luo B.. Family management in agriculture: Towards a division of labor economy. China Agricultural Press, Beijing, 2017.

[21] Li Y. and Gao L.. The formation and efficiency of the different types of forestland transfer. Soft Science, Vol.28, pp: 140-144, 2014.

[22] Ran L.. Research on Liaoning farmers' forestland circulation behavior and business efficiency in the background of collective forest tenure reform. Shenyang Agricultural University, 2011.

[23] Zhu W and Zhang L.. The impact of confirming collective forest land property rights to households on the forest land circulation behavior of farmers. Resources Science, Vol.40, pp: 1407-1417, 2018.

[24] The "Collective Forest Rights System Reform Monitoring" project team of the State Forestry and Prairie Bureau. Monitoring report on the reform of collective forest rights system in 2017. China Forestry Press, Beijing. Vol.9, pp: 39-40, 2018.

[25] Hu L.. The reality of agricultural scale management in China: The mode of "Land + Service". Issues in Agricultural Economy, Vol.11, pp:20-28, 2018.

[26] Barzel Y., Economic Analysis of Property Rights. Cambridge University Press, Cambridge, 1989.

[27] Hu X., Luo B. and Xie L.. The realization mechanism for the division of agricultural labor: Land rights subdivision and contract governance. Journal of Guangdong University of Finance \& Economics, Vol.30, pp: 33-42, 2015.

[28] Cao Z, Jiang S and Wang W. Behavioral ability, transaction cost and outsourcing of farmers' production. Journal of Agrotechnical Economics, Vol. 3, pp:64-74, 2017.

[29] Zhu W. and Luo B.. Behavioral ability, factor matching and scale farmer generation. Academic Research, Vol. 8, pp: 83-92+177, 2016.

[30] Xue C. and Liu W. Effect of behavioral ability on the income gap between forestry farmers: The regression based on the number of digits. Zhejiang Social Sciences, Vol.6, pp: 52-59+156, 2018.

[31] Shi R. and Liu W.. Research on willingness and decision of forest land circulation from the perspective of farmers' behavior ability: Data from 50 towns in 10 counties and cities in Fujian Province. Issues of Forestry Economics, Vol.37, pp:23-31+101, 2017.

[32] Kong F., Ruan H., Liao W. and Qin K.. Impact of rural labor transfer on the farmers' socialized service demand in the forestry: Survey data of 1407 households on production process. Scientia Silvae Sinicae, Vol.54, pp: 132-142, 2018. 
[33] Zhu Z, Xu Z, Shen Y, et al. How off-farm work drives the intensity of rural households' investment in forest management: The case from Zhejiang,
China[J]. Forest Policy and Economics, Vol. 5: pp30-43, 2018. 